\title{
Bioecology of Fungi-Pathogens of Flower Crops and the System to Combat Them
}

\author{
Misirova Surayyo Abdumutalovna1, Sarimsaqova Nilufar Sobirjonovna² \\ ${ }^{1}$ Tashkent State Agrarian University, Tashkent, Uzbekistan \\ ${ }^{2}$ Namangan Engineering-Pedagogical Institute, Namangan, Uzbekistan \\ Email:samisirova@mail.ru,misirova1983surayyo@mail.ru
}

Received 9 July 2016; accepted 28 August 2016; published 31 August 2016

Copyright (C) 2016 by authors and Scientific Research Publishing Inc.

This work is licensed under the Creative Commons Attribution International License (CC BY).

http://creativecommons.org/licenses/by/4.0/

(c) (i) Open Access

\begin{abstract}
For the first time, degree of damage of the disease Botrytis cinerea Pers. is founded in decorative colors in the Tashkent region. Chemical preparations are the most effective methods of struggle in the fight against diseases of ornamental crops.
\end{abstract}

\section{Keywords}

Ornamental Flowers, Fungi Types, Botrytis Disease, Degree of Damage

\section{Introduction}

Many people enjoy growing this flower in gardens or large containers. Its demand as cut flower and also as an ornamental potted plant gains importance in the world market and has a very good export potential because of its graceful appearance, hardiness and ability to withstand during transport and long shelf life. The tremendous variability in gerbera with reference to flower color, shape and size makes it more useful for cut flowers, bouquet, and decoration in marriage and landscaping in gardening. Apart from domestic consumption, it has also got export potential [1] [2].

In the work of [3] the antifungal effect of twenty powdered spice plants and their extracts at concentrations of $6 \%$, respectively was evaluated in relation to the radial mycelial growth of various soil borne fungi causing damping-off disease. The spice powder or extract was added to the culture medium PDA to obtain the proposed concentrations.

Puccinia horiana, the causal agent of chrysanthemum white rust, is a pathogen of quarantine status in many countries where Chrysanthemum morifolium cultivars are grown. Historically, identification protocols for white rust relied upon macroscopic symptom development and microscopic examination of infected leaves for telio- 
spores. Symptoms become visible 7 to 10 days after initial infection under favorable conditions followed by the production of telia. Infected plants can therefore evade detection before symptoms and fruiting bodies are evident. Conventional and real-time Polymerase Chain Reaction (PCR) assays were developed to detect $P$. horiana using primers designed to amplify portions of the Internal Transcribed Spacer (ITS) regions of the nuclear ribosomal DNA (rDNA). The species-specific primers could detect the pathogen from $1 \mathrm{ng}$ of DNA isolated from infected leaf tissue in conventional PCR assays and from $1 \mathrm{pg}$ in realtime PCR assays. While both assays were capable of detecting $P$. horiana in symptomatic tissue, the greater sensitivity offered by the real-time PCR assay made it more reliable for detecting the pathogen during the latent stage of infection. The $P$. horiana primers did not amplify the rDNA target using DNA isolated from leaf tissue infected with $P$. chrysanthemi [4].

The assortment of cultural tulips during four centuries has greatly changed; numerous cultivars and groups have been lost. Especially many cultivars disappeared in the 16th - 17th centuries when the lack of knowledge of tulips with variegated flowers caused color-broken because viral infection was highly valuated, propagated and widely distributed [5] [6]. Information of the tulip growing tradition in Lithuania and development of introductive investigations, which is divided into two periods, is presented in this work. Within the first period including years, 1972-1992, scientific investigations on tulip introduction and bulb reproduction were carried out at the Vilnius Section of Bulbous Flowers of Kaunas Botanical Garden [5] [6].

The influence of the fungicides sprayed determined coarse droplet nozzles on the healthiness of the Dark Tripoli grown in fields. This brand shows an average influence of fungicide on pathogens [7].

Decreased local species diversity is a widespread impact of human activity and may result in decreased primary production. The two major proposed mechanisms for this effect of diversity on productivity are that lower species richness decreases the probability that species with key traits will be present in the community and that a less diverse community of competing species would utilize resources less completely. In addition to these mechanisms resulting from altered competitive interactions, losses of species diversity may alter interactions such as mutualism, predation, herbivore, or infectious disease in ways that decrease primary production, but this possibility has received little attention [8]. In this work, we reported a test of the long-standing hypothesis that decreased plant species diversity increased the severity of diseases, particularly those caused by specialist plant pathogens.

For breeding promising varieties to introduce into production requires a lot of time. Thus, according to L. A. Abdurahmanov and A. V. Abramov (1991), for the Botanical Garden of the Republic of Uzbekistan time after receipt of a sample of its final assessment of introduction is 7 - 10 years. To speed up the process for many valuable ornamental plants, including hybrid tea roses vegetative, greatly contributes to propagation by stem cuttings based on the ability of living tissues and regeneration of adventitious roots [9].

The advantage of these measures is high efficiency and speed of action, availability, ease of use. However, along with the positive aspects of the use of the chemical method has significant drawbacks, which are at risk of pesticide contamination of the environment, but with the right application and the selection of the range of products you can minimize the negative effects of pesticides [10].

The chemical method is the fastest, easily accessible and in the case of ornamental floriculture profitable. The effectiveness of the above method is largely determined by the presence of the necessary range of pesticides, which is currently very high.

Reliable plant protection can only be achieved using a system of integrated protection of the struggle, i.e., a combination of agro-technical, mechanical, chemical and biological weapons, if possible, depends on the specific task at hand [10].

In the works of [11] [12], samples of 658 herbaria from 15 decorative flowers of plants in the field and greenhouses in Tashkent region were determined. Of them pathogen disease separation determined 65 types of fungi to 9 forms and 1 variant.

A few details on the effectiveness of fungicides to fight diseases of ornamental crops, and the lack of data on the use of new fungicides to combat fungal diseases, have formed the basis for the study of the impact of these chemicals on plant disease susceptibility. We have studied the possibility of applying fungicides in plant protection capabilities of ornamental crops.

The aim of this work was to study the efficacy of fungicides to combat disease and rot of planting material in a Tashkent region. 


\section{Material and Methods}

The material works were decorative plants: gladiolus, narcissus and tulips.

Prophylactic methods are called a warning of occurrence and spread of the disease. According to many authors [13]-[17], phytosanitary measures are aimed at suppressing the sources of infection. The sources, due to which there is an infection of plants in the next growing season, can be infected plant residues, wintering diseased plants, seeds and planting material and other. Hence, the basis of these methods is to create unfavorable conditions for the existence of pathogens and increased resistance of cultivated plants to diseases.

The humidity in the greenhouse was maintained in the range $90 \%-95 \%$, the temperature is not higher than $30^{\circ} \mathrm{C}$.

Growing in winter conditions (landing in November-December) was produced in containers made of polyethylene film containing a greenhouse, since the spring directly at the place of use.

A comparative study of bio-morphological characteristics of grafted and own-rooted plants, each variant of the experiment were observed at 25 plants most ornamental varieties of roses each group, grown by the same technology. Statistical processing was performed by G. F. Lakinu [18].

There are numerous reports of high antagonistic activity of Trichoderma against a number of pathogenic microorganisms such as root rot pathogens of crops, Rhizoctonia, Sclerotinia, Blight Wheat, Verticillium, Fusarium wilt of cotton, Fusarium diseases of vegetables and potatoes. S. N. Moskovets and others have established the efficacy of the fungus Trihoderma lignorium to combat diseases of crop plants [19].

Mathematical processing of digital research results carried out using conventional statistical methods [20] [21] with the use of specialized computer software package EXCEL and Maple 9.5.

\section{Results}

\subsection{Determining Degree of Damage the Disease Botrytis cinerea Pers. Found in Decorative Flowers}

Botrytis cinerea Pers. of tulips. Tulips, like any other ornamental plants, damaged a large number of different diseases. There are many different fungal diseases of tulips, but the greatest harm it causes Botrytis cinerea Pers.

The causative agent, a parasitic fungus Botrytis, a close relative of the types of fungus that cause rot of onion, cabbage and many other ornamental and food plants. Other species are also found in the botrytis tulips and cause rot, and even spotted a specific botrytis. However, a gray rot is most common. Typically, the source of infection, patients are planted bulbs or soil that contains the infected plant residues. Botrytis cinerea Pers. affects all aerial parts of tulips (leaves, stems, flowers, and buds) and bulbs. The ubiquitous fungus spores can get to the bulb as in the growing season and during storage, and then either immediately begin to develop, either waiting for the right conditions. Most noticeably Botrytis cinerea Pers. appears in rainy and cool weather-ideal conditions for the growth and development of fungus-parasite. Usually in this case the disease spreads very quickly.

Although Botrytis cinerea Pers. can affect tulips at all stages of development, they are particularly susceptible during budding. The incubation period under favorable conditions amounts to only $1-3$ days. The spread of the disease contribute to high humidity of soil and air, dense plantation, the lack of brightness, excess nitrogen in the soil and spring frosts.

This disease is usually well discernible even in the early stages of development. Affected bulbs are on the outer scales yellow-brown spots in a reddish halo. On other affected parts of the plant appear yellowish gray sunken spots of various sizes and shapes. If conditions are wet, the spot sizes are rapidly increasing, and they are covered with gray bloom of spores. Over time, the tissue of diseased plants dry up gradually soften and become ash-gray. It looks as if the plant is burned and covered with as, Hence another name for this disease- - "burn tulip".

With strong development of the disease is curved stem tulip, buds do not develop, and if the colors and images, they are deformed, ugly forms. Patients' tulips die prematurely, so their vegetation period is considerably reduced. As a result, the bulbs cannot grow to normal size and gradually shrinking.

During storage, the disease may continue to develop rapidly: the affected bulbs to soften, darken and shrivel, sometimes Donets bulbs crack from the center to the edges. In severe cases tulip bulb botrytis rot during storage, resulting in destroying it. But if the disease is barely noticeable, inexperienced grower may accidentally miss spotting appeared in the rejection of the bulbs. It is extremely dangerous if the infected bulbs are planted in the 
soil in the spring it will weakened, twisted shoots, which will gradually become brown, covered with gray bloom and die. The spores of the fungus from such plants are carried by wind and infect healthy plants.

Botrytis cinerea Pers. Narcissus. Narcissus-beautiful spring bulbs, universal possibilities for use. They are indispensable in gardening, give wonderful Slitter material, suitable for winter forcing. They differ unpretentious to the growing conditions. The scale cultivation belongs to the three leading cultures of the world, along with roses and chrysanthemums. Narcissus is the genus of the family Amaryllidaceous, herbaceous bulbous perennial plants. It consists of the bulbs, leaves, flower shoots, flowers and fruit. The above-ground part of his annually dies, retained only underground bulb, which is a modified shoot with short flat stem and fleshy leaves colorless (scales), adapted for the accumulation of nutrients. Scales closely overlapping one another and form around the point of growth almost clasped concentric circles. At the base, each of the scales formed axillary buds that gave to rise daughter plants. They are formed from young tissues bulbs, allowing for a long time daffodils renewed vegetative. The bulb is always in a state of development. After the death of aerial organs in the kidney renewal actively proceed the processes of formation of flower shoots and flowers, and laid new kidney regeneration. New Scale and axillary's buds are formed in the central portion of the bulb. Expanding, bulb consumes nutrient reserves of the peripheral scales that are constantly dying, turning into a protective shell. Axillary's buds are released and become independent plants (the children). The size and shape of the bulb depends on its age and varietals characteristics. There are circular single-vertex, bimodal and many peaks bulb. Subsidiaries bulbs from the fit to the parent have a flattened shape.

The root system is fibrous and daffodils formed of updated annually paranasal threadlike roots, which are located at the bottom of the outer part of the stems. They are laid in a summer of rest and appear on the bulb in the fall. Besides the usual roots of daffodils there is also retractable to facilitate burial bulbs in the soil. They appear in small and medium-sized bulbs, as well as a shallow (up to $10 \mathrm{~cm}$ ) landing. The lifespan of roots $11-12$ months, then they gradually die off. In August, it begins the growth of new roots, and in the autumn they grow most rapidly. In years with excess moisture dying old roots delayed. With long-term storage of the bulbs in high humidity regrowth of roots it begins in the store. This is, of course, very bad, since the grading and planting the roots can break off. They subsequently resumed due to inventory bulbs, but these plants are poorly developed.

Narcissus in comparison with other bulbous crops suffers less from diseases and pests. Botrytis cinerea Pers. - a disease rapidly developing spring in cold rainy weather, especially in depressed areas with heavy soils. The plant infected in the field and during storage of bulbs in cold and wet conditions, the disease progresses. Leaf hits the ground, especially on one side, which is formed brown sunken spots, which subsequently grow. The leaves turn yellow from the bottom up and dry out before flowering. With an excess of moisture in the areas of dead leaf appears gray powder, small spots on the flowers, and bulbs on wet rot. On the surface of the affected tissues are formed black sclerotia.

Gladiolus genus belongs to the family Iridaceae. There are about 180 species of gladiolus, distributed mainly in subtropical and tropical areas of South Africa. In Europe, these flower gardens have been cultivated since the late seventeenth century, when it was imported from South Africa. All modern varieties are a cultural sight Gladiolus hybrid. In order to get a nice healthy flower, and then a healthy planting gladiolus - a new bulb, which is formed at the end of the growing season — when growing gladioli is necessary to consider several factors.

Gladiolus demanding on soil fertility, but cannot tolerate an excess of mineral salts. The best soil for growing gladioli is loam or sandy loam with high humus content. The optimum soil acidity is $\mathrm{pH} 5.5-6.0$, but not greater than 6.5. Raising or lowering the $\mathrm{pH}$ leads to a significant defeat bulbs bacterial and fungal diseases.

I daresay that few gardeners and farmers have the opportunity to test the acidity of the soil on the site. Nevertheless, in their garden plots we grow beautiful flowers, including gladiolus, and vegetable crops. Of course, if you have the opportunity to consider all factors when growing crops and provide them with optimal conditions, the plants are more resistant to diseases and adverse weather conditions.

The life cycle is closed and gladiolus does not stop even when the bulbs are in winter storage. How healthy and beautiful will be your gladioli flowers next season depends on how you grow gladioli in nineshnem-how to care for them during the growing season, flowering, after flowering. Insufficient attention you can get a beautiful flower (if there was a healthy planting material), while digging to discover the ugly underdeveloped bulb.

I repeatedly had to deal with similar examples. Man gained a healthy beautiful gladiolus bulb planted happy bloom and in the autumn when digging was disappointed to view the new bulbs. Although there are cases when a complete disregard all methods of farming in growing gladioli growers receive and beautiful flower and beautiful planting. Obviously, these people have favorable conditions for growing gladiolus against their will. I was 
convinced from personal experience: miss fines in growing gladioli - lost grade or, in the best case, season.

Botrytis cinerea Pers. gladioli refer to fungal diseases. The cause of the disease is a fungus Botrytis cinerea Pers. Therefore, the disease is sometimes called by the name of the fungus, the pathogen or Botrytis cinerea Pers.

In the process of doing research work in the region is the most common and most dangerous pathogen fungi species of flower plants to determine the level of disease initiation of patient given special attention. We have obtained the results shown in Figure 1.

The results obtained are as follows:

$\begin{array}{lccc} & \text { For the } 2013 \text { year: } & \text { For the } 2014 \text { year: } & \text { For the } 2015 \text { year: } \\ \text { Gladiolus (Tourn.) L. } & 29.3 \% & 31.0 \% & 22.9 \% \\ \text { Narcissus L. } & 25.9 \% & 23.7 \% & 26.4 \% \\ \text { Tulipa L. } & 23.9 \% & 20.4 \% & 24.2 \%\end{array}$

\subsection{The Effectiveness of Application of Fungicides in the Fight against Rot and Disease Planting Material}

One important factor negatively affecting the life of the plant reducing their productivity, longevity and decorative qualities are fungal diseases.

Plant diseases are not frozen, not a static phenomenon but a dynamic process, during which the physiological, biochemical, anatomical and morphological changes, manifested by certain specific symptoms and eventually caused the decrease in the quantity and quality of the crop. This disruption of normal metabolism, cells, organs and whole plant, arises under the influence of the phytopathogen and leads to a decrease in productivity of plants or their complete destruction.

Diseased plants—a kind of biological system in which the growth and development of two organisms—plants and the pathogen. The pathogen enters the plant violates the integrity of the cells takes one nutrients moves from cell to cell and eventually may spread throughout the plant. Simultaneously, the causative agent of constant

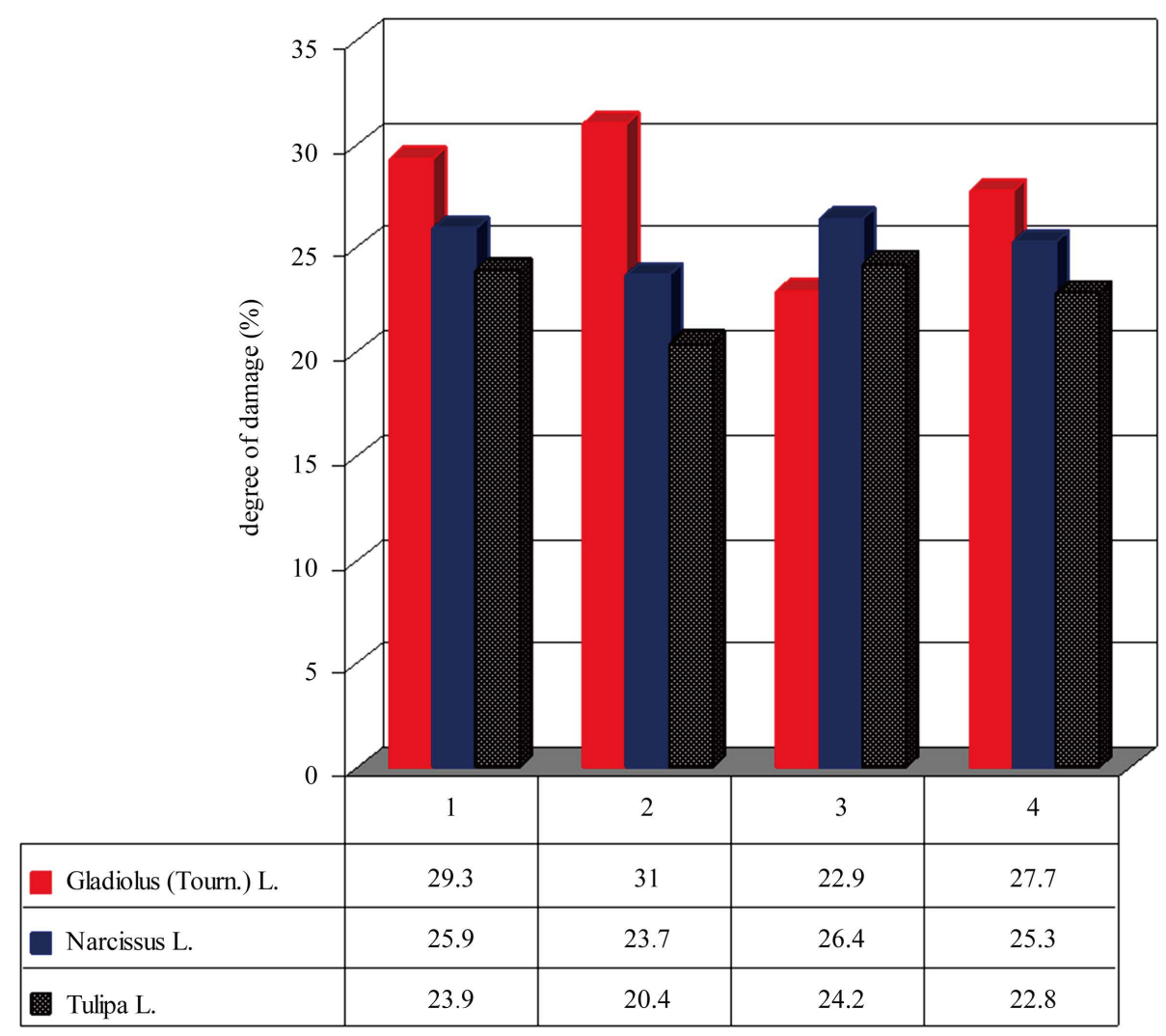

Figure 1. Determining degree of damage the disease Botrytis cinerea Pers. occurring in the decorative flowers 
exposure to the plant cell by using its product life. Stay in the plant pathogen breaks the normal process of life of the latter.

The concept of plant diseases is one of the main provisions of general plant pathology and is essential for building a system of measures, which lay the foundation conditions for the appearance and character of the disease.

As mentioned above, one of the most effective methods of combating plant diseases, especially fungal nature is a chemical method or the use of fungicides - substances toxic to pathogens. Since, in the list of pesticides permitted for use in Uzbekistan is practically not given data on the use of fungicides on flower-ornamental plants, one of the challenges facing us was to identify suitable drugs for the prevention of and the fight against major diseases flower crops.

Also it should be noted that the importance of preventing diseases in plants is given protection during their most delicate development — when planting them in the ground, often observed when high rot.

In this connection, we have studied in the dressing bulbs and corms of flowering plants (narcissus, tulips, gladioli), and presuming carnation cuttings. Chemical treatment of bulbs and tubers are recommended fungicide after digging or before planting. To protect the cuttings before planting should be within $10-15$ minutes to maintain them in suspension formulations.

Etching planting material has a protective function in keeping the germination and seedlings from root rot. The search for effective disinfectants in the fight against Fusarium and other root rots is of great economic interest.

With a view to finding an effective disinfectant contact has been tested a number of drugs that have shown good results against root rots of many crops.

To do this in advance, 1 month before sowing, carried dressing corms bulbs and flower crops.

In the fight against Fusarium were tested the following disinfectants: Barak, $60 \% \mathrm{wp}(1.0$ and $2.0 \mathrm{~kg} / \mathrm{t} \mathrm{ac}-$ cording to the recommended application rates), Maxim, 2.5\%, KS (0.2 and $0.4 \mathrm{l} / \mathrm{t}), 200$ Vitavaks $75 \%$ wp (3.0 and $4.0 \mathrm{~kg} /$ tonne) and TOPS-M, 70\% wp (1.0 to $1.5 \mathrm{~kg} /$ tonne). As a reference, used fundazol, 50\% wp (2.0 $\mathrm{kg} /$ tonne) which gives good results in combating root rot of many crops.

The experiments were laid in lysimeters of $1 \mathrm{~m}^{2}$. For five days before the sowing of the plants in the soil was added pure culture of Fusarium grown on sterilized oat, based on $30 \mathrm{~g}$ of each hypsometer. The test was conducted in $4 \mathrm{x}$ times again.

Shoots depend on the culture there for 6 - 8 days. The surveys were carried out, starting with mass destruction, every 3 days.

The data presented in Table 1 show that in the control variant without treatment susceptibility gladiolus Fusarium reached $31.0 \%$, daffodils $35.5 \%$ and tulips $28.5 \%$.

Of the tested disinfectants on gladioli in the first place performance is Maxim, at a rate of $0.4 \mathrm{l} / \mathrm{t}$ biological efficacy of this drug reached to $85.1 \%$, and normally $0,2 \mathrm{l} / \mathrm{m} 81.2 \%$.

The second highest cost efficiency protects Topsin-M. At a rate of $1.5 \mathrm{~kg} / \mathrm{t}$ of Fusarium susceptibility of 4.6\%, where the biological efficiency was $77.2 \%$. With decreasing flow rate of $1.0 \mathrm{~kg} / \mathrm{ton}$, decreased biological efficacy and did not exceed 59\%. Biological efficacy Vitavaks (4.0 kg/tonne) and Barrack (2.0 kg/t) was 73.5 and $65.3 \%$ respectively.

Disinfectants Maxim also showed good results against Fusarium daffodils and tulips. The biological efficacy of disinfectant was $85.9 \%$ and $77.8 \%$, which is above or close to the standard - fundazol $(81.1 \%$ and $84.2 \%$, respectively).

Thus, in the fight against dangerous disease ornamentals Fusarium in manufacture can be recommended seed protectants Maxim in a rate of $1.5 \mathrm{l} / \mathrm{m}$ and Topsin-M $1.5 \mathrm{~kg} / \mathrm{t}$.

In the case of processing plants cloves, widely used where cuttings was conducted a similar experience. As a fungicide used fundazol, $50 \%$ wp at application rates of 1.0 and $2.0 \mathrm{~kg} / \mathrm{ha}$, Topsin-M, 70\% wp (1.0 and 1.2 $\mathrm{kg} / \mathrm{hectare}$ ) and Bayleton 25\% wp (0.75 and $1.0 \mathrm{~kg} / \mathrm{ha})$.

From Table 2, it is clear that in the absence of keeping the cuttings in suspension preparations the percentage of infected plants was $27.3 \%$.

From the three investigated fungicide fundazol showed the best results, the biological effectiveness of which was equal to $86.4 \%$ - 90.4\%, followed by Bayleton (82.7\% - 84.1\%). Biological efficiency Topsina-M was $77.2 \%$.

The results indicate that the proposed increase in the manifestation of a measure to prevent rot in the technology of cultivation of carnations reduce their appearance is at least 4 times. 
Table 1. The biological efficacy of disinfectants against Fusarium (Tashkent region Kibray district "Shomil” and "Adolat” private floriculture farms , 2013-2015 years).

\begin{tabular}{|c|c|c|c|c|c|}
\hline Variants & $\begin{array}{c}\text { The application rate, } \\
\text { l/t kg/ha }\end{array}$ & $\begin{array}{l}\text { The number } \\
\text { of shoots, pc }\end{array}$ & $\begin{array}{c}\text { Of these diseased, } \\
\text { pc }\end{array}$ & $\begin{array}{c}\text { Degree of damage } \\
\%\end{array}$ & $\begin{array}{c}\text { The biological efficacy } \\
\%\end{array}$ \\
\hline 1 & 2 & 3 & 4 & 5 & 6 \\
\hline \multicolumn{6}{|c|}{ Gladiolus } \\
\hline Control & - & 386 & 120 & 31.0 & - \\
\hline Fundazol (standart) & 2.0 & 436 & 34 & 7.7 & 75.1 \\
\hline \multirow[b]{2}{*}{ Maksim } & 0.2 & 448 & 26 & 5.8 & 81.2 \\
\hline & 0.4 & 449 & 21 & 4.6 & 85.1 \\
\hline \multirow{2}{*}{ Topsin-M } & 1.0 & 408 & 52 & 12.7 & 59.0 \\
\hline & 1.5 & 401 & 25 & 6.2 & 77.2 \\
\hline \multirow[b]{2}{*}{ Vitavaks } & 3.0 & 415 & 46 & 11.0 & 64.5 \\
\hline & 4.0 & 422 & 35 & 8.2 & 73.5 \\
\hline \multirow{2}{*}{ Baraka } & 1.0 & 412 & 51 & 12.3 & 60.3 \\
\hline & 2.0 & 423 & 46 & 10.8 & 65.3 \\
\hline \multicolumn{6}{|c|}{ Narcissus } \\
\hline Control & - & 456 & 162 & 35.5 & - \\
\hline Fundazol (standart) & 2.0 & 551 & 37 & 6.7 & 81.1 \\
\hline \multirow{2}{*}{ Maksim } & 1.0 & 559 & 32 & 10.0 & 83.9 \\
\hline & 1.5 & 571 & 29 & 5.7 & 85.9 \\
\hline \multirow{2}{*}{ Topsin-M } & 1.0 & 544 & 49 & 9.0 & 74.6 \\
\hline & 1.5 & 436 & 34 & 7.7 & 75.1 \\
\hline \multirow{2}{*}{ Vitavaks } & 3.0 & 530 & 71 & 13.3 & 62.5 \\
\hline & 4.0 & 536 & 54 & 10.0 & 71.8 \\
\hline \multirow{2}{*}{ Baraka } & 1.0 & 519 & 110 & 21.1 & 40.5 \\
\hline & 3.0 & 536 & 101 & 18.8 & 47.0 \\
\hline \multicolumn{6}{|c|}{ Tulips } \\
\hline Control & - & 291 & 83 & 28.5 & - \\
\hline Fundazol (standart) & 2.0 & 348 & 16 & 4.5 & 84.2 \\
\hline \multirow{2}{*}{ Maksim } & 1.0 & 334 & 26 & 7.7 & 72.9 \\
\hline & 1.5 & 349 & 22 & 6.3 & 77.8 \\
\hline \multirow{2}{*}{ Topsin-M } & 1.0 & 316 & 34 & 10.7 & 62.4 \\
\hline & 1.5 & 328 & 32 & 8.5 & 73.5 \\
\hline \multirow{2}{*}{ Vitavaks } & 3.0 & 318 & 33 & 10.3 & 63.8 \\
\hline & 4.0 & 326 & 28 & 8.5 & 70.1 \\
\hline \multirow{2}{*}{ Baraka } & 1.0 & 314 & 52 & 16.5 & 42.1 \\
\hline & 2.0 & 326 & 38 & 11.6 & 59.2 \\
\hline
\end{tabular}


Table 2. The biological efficacy of fungicides against rot in the cuttings carnations (Tashkent region Kibray district "Shomil” and “Adolat” private floriculture farms , 2013-2015 years).

\begin{tabular}{|c|c|c|c|c|c|c|}
\hline № & Variants & $\begin{array}{c}\text { The application rate, } \\
\text { 1/t kg/ha }\end{array}$ & $\begin{array}{l}\text { The number } \\
\text { of shoots, pc }\end{array}$ & $\begin{array}{l}\text { Of these } \\
\text { diseased, pc }\end{array}$ & $\begin{array}{c}\text { Degree of } \\
\text { damage \% }\end{array}$ & $\begin{array}{c}\text { The biological } \\
\text { efficacy, } \%\end{array}$ \\
\hline 1. & Control & - & 358 & 98 & 27.3 & - \\
\hline \multirow{2}{*}{2.} & \multirow{2}{*}{ Fundazol (standart) } & 1.0 & 459 & 17 & 3.7 & 86.4 \\
\hline & & 2.0 & 389 & 11 & 2.8 & 90.4 \\
\hline \multirow{2}{*}{3.} & \multirow{2}{*}{ Bayleton } & 0.75 & 425 & 20 & 4.7 & 82.7 \\
\hline & & 1.0 & 327 & 18 & 5.5 & 84.1 \\
\hline 4. & Topsin-M & 1.0 & 401 & 25 & 6.2 & 77.2 \\
\hline
\end{tabular}

\section{Conclusion}

Chemical preparations are the most effective methods of struggle in the fight against diseases of ornamental crops. In the fight against protection from Fusarium ornamentals in the manufacture can be recommended as planting material disinfectants-Maxim at a rate of $1.5 \mathrm{l} / \mathrm{t}$ Topsin-M and $1.5 \mathrm{~kg} / \mathrm{t}$. In the case of processing plants cloves, where cuttings is widely used as a fungicide before planting, it is recommended to use fundazol, $50 \%$ wp at application rates of 1.0 and $2.0 \mathrm{~kg} / \mathrm{ha}$, Topsin-M, 70\% wp (1.0 and $1.2 \mathrm{~kg} / \mathrm{hectare}$ ) and Bayleton $25 \%$ (0.75 and $1.0 \mathrm{~kg} / \mathrm{ha})$.

\section{References}

[1] Kumar, S., Tomar, K.S. and Shakywar, R.C. (2012) Response of Gerbera Varieties against Powdery Mildew Disease under Polyhouse Condition. Hortflora Research Spectrum, 1, 286-288.

[2] Nagrale, D.T., Gaikward, A.P. and Sharma, L. (2013) Morphological and Cultural Characterization of Alternaria alternata (Fr.) Keissler Blight of Gerbera. Journal of Applied and Natural Science, 5, 171-178.

[3] El-Mougy, N.S. and Abdel-Kader, M.M. (2007) Antifungal Effect of Powdered Spices and Their Extracts on Growth and Activity of Some Fungi in Relation to Damping-Off Disease Control. Journal of Plant Protection Research, 47, 267-278.

[4] Pedley, K.F. (2009) PCR-Based Assays for the Detection of Puccinia horiana on Chrysanthemums. Plant Disease, 93, 1252-1258. http://dx.doi.org/10.1094/PDIS-93-12-1252

[5] Juodkaitè, R., Baliūneinè, A., Naujalis, J.R., Navalinskienė, M. and Samuitienè, M. (2008) Selection and Presentation of Tulip (Tulipa L.) Species and Cultivars to the Lithuanian Plant Genetic Resources. Biologija, 54, 139-146. http://dx.doi.org/10.2478/v10054-008-0029-1

[6] Juodkaite, R., Naujalis, J.R., Navalinskienė, M. and Samuitienė, M. (2005) Evaluation of Tulip (Tulipa L.) Decorative Capacities and Resistance to Tulip Breaking potyvirus in the Tulip Collection of the Botanical Garden of Vilnius University. Biologija, 51, 64-70.

[7] Parafiniuk, S. and Kopacki, M. (2012) Biological Efficacy of the Chemical Chrysanthemums Protection with the Use of Fine and Coarse Droplets. Journal of Central European Agriculture, 13, 554-559. http://dx.doi.org/10.5513/jcea01/13.3.1090

[8] Mitchell, C.E., Tilman, D. and Groth, J.V. (2002) Effects of Grassland Plant Species Diversity, Abundance and Composition on Foliar Fungal Disease. Ecology, 83, 1713-1726. http://dx.doi.org/10.1890/0012-9658(2002)083[1713:EOGPSD]2.0.CO;2

[9] Abdurakhmanov, L.A. and Abramov, A.B. (1991) Dynamics and Flowering of Some Varieties of Hybrid Tea Roses in the Botanic Garden. Fan, Tashkent, 41-44.

[10] Sinadsky, Y.V., Korneev, I.T. and Dobrochinskaya, I.B. (1982) Pests and Diseases of Decorative Flower Plants. Science, Moscow, p. 592.

[11] Misirova, S.A. (2015) Systematic Types of Fungi of Allocated and Determined Types from Decorative Flowers in Conditions Region Tashkent. Agricultural Science, 6, 1387-1392. http://dx.doi.org/10.4236/as.2015.611134

[12] Misirova, S.A. (2016) Determining of the Measure Disease Control Ornamental Crops during the Growing Season in the Conditions Tashkent Region. Global Journal of Bio-Science and Biotechnology, 5, 427-429. 
[13] Van der Plank (1966) Plant Diseases (Epiphytotics and Fighting Take off). Kolos, Moscow, p. 359.

[14] Tarr, S. (1985) Basics of Plant Pathology. Mir, Moscow, p. 587.

[15] Roberts, D. (1981) Basics of Plant Protection. Mir, Moscow, p. 254.

[16] Popkov, K.V. (1989) Basics of Plant Pathology. Agropromizdat, Moscow, p. 399.

[17] Ruzaeva, I.V. (2007) Resistance to Diseases of Garden Roses. Samara Bend. Byul. Russia, 16, 91-109.

[18] Lakin, G.F. (1990) Biometrics. Higher School, Moscow, p. 352.

[19] Moskovets, S.N. and Sergeev, L.A. (1961) The Value of the Fungus Trichoderma koningii Oudem. in the Fight against Diseases of Crop Plants. House, Armenian SSR, p.133

[20] Zaitsev, G.N. (1984) Mathematical Statistics in Experimental Botany. Science, Moscow, p. 424.

[21] Borovikov, B. (2001) Statistica: The Art of Data Analysis on the Computer. Peter, St. Petersburg, p .656.

\section{Submit or recommend next manuscript to SCIRP and we will provide best service for you:}

Accepting pre-submission inquiries through Email, Facebook, LinkedIn, Twitter, etc.

A wide selection of journals (inclusive of 9 subjects, more than 200 journals)

Providing 24-hour high-quality service

User-friendly online submission system

Fair and swift peer-review system

Efficient typesetting and proofreading procedure

Display of the result of downloads and visits, as well as the number of cited articles

Maximum dissemination of your research work

Submit your manuscript at: http://papersubmission.scirp.org/ 